\title{
Black and white teas as potential agents to combine with amphotericin $B$ and protect red blood cells from amphotericin B-mediated toxicity
}

\author{
V. M. Oliveira ${ }^{a *}$, N. M. Khalil ${ }^{b}$ and E. Carraro $^{a}$ \\ a'Laboratório de Virologia, Programa de Pós-graduação em Ciências Farmacêuticas, Departamento de Farmácia, \\ Universidade Estadual do Centro-Oeste - UNICENTRO, Rua Simeão Camargo Varelá de Sá, nº 3, CEP 85040-080, \\ Guarapuava, PR, Brazil \\ 'Laboratório de Nanotecnologia Farmacêutica, Programa de Pós-graduação em Ciências Farmacêuticas, Departamento \\ de Farmácia, Universidade Estadual do Centro-Oeste - UNICENTRO, Rua Simeão Camargo Varelá de Sá, nº 3, \\ CEP 85040-080, Guarapuava, PR, Brazil \\ *e-mail: vmatoso19@gmail.com
}

Received: November 8, 2016 - Accepted: July 12, 2017 - Distributed: November 30, 2018

(With 1 figure)

\begin{abstract}
Amphotericin B is a fungicidal substance that is treatment of choice for most systemic fungal infections affecting immunocompromised patients. However, severe side effects have limited the utility of this drug. The aim of this study was to evaluate the antifungal effect of the combination of amphotericin B with black tea or white tea and protective of citotoxic effect. The present study shows that white and black teas have additive effects with amphotericin B against some species Candida. In addition, the combination of white and black tea with amphotericin B may reduce the toxicity of amphotericin B to red blood cells. Our results suggest that white and black tea is a potential agent to combine with amphotericin for antifungal efficacy and to reduce the amphotericin dose to lessen side effects.
\end{abstract}

Keywords: amphotericin B, antifungal., black tea, Camellia sinensis, white tea, toxicity.

\section{Chá preto e branco de Camellia sinensis como potenciais agentes para associar com anfotericina $B$}

\begin{abstract}
Resumo
A anfotericina B é o tratamento de escolha para a maioria das infecções fúngicas sistémicas que afetam os doentes imunocomprometidos. No entanto, efeitos secundários graves têm limitado a utilidade desta droga. O objetivo deste estudo foi avaliar o efeito antifúngico da combinação de anfotericina B com chá preto ou chá branco, bem como o efeito citotóxico desta combinação sobre hemáceas. O presente estudo demonstra que o chá branco e preto de Camellia sinensis têm efeitos aditivos com anfotericina B contra algumas espécies de Candida sp. Além disso, a combinação de chá branco e preto com anfotericina B pode reduzir a toxicidade da anfotericina B em hemáceas. Nossos resultados sugerem que o chá branco e preto são agentes potenciais para associação com anfotericina $\mathrm{B}$ contribuindo para eficácia antifúngica, bem como redução de toxicidade.
\end{abstract}

Palavras-chave: anfotericina B, antifúngico, chá preto, Camellia sinensis, chá branco, toxicidade.

\section{Introduction}

Candida species are the most common cause of opportunistic fungal disease. Candida spp. is responsible for approximately $80 \%$ of fungal infections in hospitals and are the fourth most common nosocomial pathogen (Colombo and Guimaraes, 2003). Furthermore, candidemia has mortality rates between 40 and $60 \%$, the diagnosis and treatment are difficult and expensive (Colombo et al., 2006; Tumbarello et al., 2007; Wenzel, 1995).

The treatment of these infections is based on the use of azole antifungal drugs such as ketoconazole, miconazole, itraconazole, fluconazole, and voriconazole (Pfaller, 2012).

Following its discovery in 1953, amphotericin B (amB) has remained the treatment of choice for most systemic fungal infections affecting immunocompromised patients (Pagano et al., 2010). However, severe side effects, infusion-related toxicities, the frequent association whit renal damage and the intravenous formulation of amB, have limited the utility of this drug (Sawaya et al., 1995). Therefore numerous attempts have been made in recent years to reduce amB toxicity. Among these new developments, formulations such as a liposomal encapsulation base, lipid complexes, colloidal dispersions and nanoparticles have 
been shown to cause less toxicity and increase therapeutic efficacy, but the high cost of these formulations have limited their use (Filippin and Souza, 2006; Fukui et al., 2003; Jung et al., 2009). Thus, reducing the amB dose by combining it with new antifungal products appears to be an important approach, as shown by Rosato et al. (2008), who demonstrated that essential oils increased the in vitro antifungal activity of amB against Candida spp (Rosato et al., 2008).

Previous work has demonstrated the antifungal activity of white and black teas, which is due to the differential preparation of the terminal leaves and apical buds of the plant Camellia sinensis (L.) (Almajano et al., 2008; Friedman, 2007; Sitheeque et al., 2009). One study demonstrated that the antifungal activity of these teas and their individual component, theaflavin digallate inhibited the growth of Trichophyton mentagrophytes and Trichophyton rubrum (Okubo et al., 1991). Another study showed that that a combined effect between epigallocatechin gallate and amB blocked the formation of C. albicans hyphae (Han, 2007a). Black tea also increased the antibacterial activity of the several antibiotics, such as chloramphenicol, gentamicin, methicillin and nalidixic acid against some enterobacteria (Tiwari et al., 2005). The aim of this study was to evaluate the antifungal effect of the combination of amphotericin B with black tea or white tea and the potential protective effect of black and white teas on amB cytotoxicity in red blood cells.

\section{Materials and Methods}

\subsection{Reagents and chemicals}

Liquid RPMI1640 medium with L-glutamine and without sodium bicarbonate, morpholinepropanesulfonic acid (MOPS) and dimethyl sulfoxide (DMSO) was purchased from Sigma ${ }^{\circledR}$ (St. Louis, MO, USA), and trypan blue was purchased from Vetec ${ }^{\circledR}$ (São Paulo, Brazil). Amphotericin B (IffectChemphar Co. Ltd., China) was kindly donated by local vendor. All other chemicals were of analytical grade and of the highest commercially available purity. White and black teas (Prenda ${ }^{\circledR}$, Brazil) were purchased from a retail market.

\subsection{Tea infusion}

The tea infusion stocks were prepared from $0.5 \mathrm{~g}$ of dry leaves and $25 \mathrm{ml}$ of boiling sterile water or PBS $(0.85 \%$ $\mathrm{NaCl}, 50 \mathrm{mM}$ sodium phosphate, $\mathrm{pH}$ 7.4). Each sample was incubated for 30 minutes at room temperature and then filtered. The tea infusions were then frozen at $-20{ }^{\circ} \mathrm{C}$ (Bancirova, 2010). The concentrations are expressed according to the dry weight, according to guidelines established by the Brazilian Pharmacopoeia (ANVISA, 2010).

\subsection{Antifungal activity}

Strains: Candida albicans (ATCC 14053 and 64546) and Candida krusei (ATCC 6258) strains were used as a reference and eight different clinical isolates of Candida spp were evaluated in this study. Antifungal activities were determined by broth microdilution using serial dilutions in RPMI 1640 medium, as described by the Clinical and
Laboratory Standards Institute (2008), method M27-A3 with some modifications.

Medium: RPMI 1640 medium, buffered with $0.165 \mathrm{M}$ MOPS, was used for in vitro antifungal analyses. The medium was adjusted to $\mathrm{pH} 7.0$ with $1.0 \mathrm{M}$ sodium hydroxide $(\mathrm{NaOH})$ and filtered. An amB stock solution was prepared in DMSO, and stock solutions of white tea and black tea was prepared in sterilized water. Medium alone inoculated with the fungal strain was used as a growth control, and uninoculated medium was used as the blank control. Sterile 96-well microtiterplates were prepared with serial dilutions of the compounds. Cell suspensions of Candida spp strains were prepared in RPMI medium and adjusted to give final inoculum concentrations of $0.5 \times 10^{3}-2.5 \times 10^{3} \mathrm{CFU} / \mathrm{ml}$. The cells were incubated with different concentrations of white tea and black tea and/or amB at $37^{\circ} \mathrm{C}$ for 24 hours. The minimum inhibitory concentration (MIC) was defined as the lowest concentration that does not result in any visible growth of the yeast compared to the control. Synergistic activity was determined by incubating cells with the teas and amB, both at subinhibitory concentrations. The fractional inhibitory concentration index (FICI) was defined as the sum of the MIC of each drug when used in combination divided by the MIC of the drug used alone. FICI values were interpreted as follows: $\mathrm{FICI} \leq 0.5$, synergistic; $0.5<\mathrm{FICI} \leq 1$, synergistic to additive; $1<\mathrm{FICI} \leq 4$, indifferent; and $\mathrm{FICI}>4$, antagonistic (Arikan et al., 2002; Odds, 2003). The Ethics Committee of the UniversidadeEstadual do Centro-Oeste, Guarapuava, Brazil, approved all experiments.

\subsection{Cytotoxicity to human erythrocytes in vitro}

\subsubsection{Preparation of erythrocyte suspension}

Freshly collected human blood, obtained from one healthy donor, was treated with heparin and centrifuged at $2500 \mathrm{rpm}$ for $5 \mathrm{~min}$ to separate the plasma from the erythrocytes. The pelleted erythrocytes were washed three times with isotonic PBS (pH7.4), and the supernatant was carefully removed after each wash. After the final wash, the packed cells were re-suspended in PBS, and the hematocrit was determined (Koga et al., 1998).

\subsubsection{Hemolysis assay}

The hemolysis studies were performed with erythrocytes suspended in PBS $(0.9 \mathrm{~mL})$ at a hematocrit of $5 \%$. A $0.02 \mathrm{~mL}$ volume of amB $(16 \mu \mathrm{g} / \mathrm{mL})$ in DMSO was added to the cell suspension. The final DMSO concentration in the suspension had no effect on the erythrocytes. The teas were added to the suspensions at different concentrations

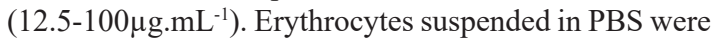
used as a blank control. The suspensions were incubated for 7 hours at $37^{\circ} \mathrm{C}$ with continuous shakingin the dark. After incubation, the erythrocyte suspensions were centrifuged at 2500rpm for $5 \mathrm{~min}$ and the hemolysis degree was estimated by visible spectroscopy at $540 \mathrm{~nm}$ from the hemoglobin released into the supernatant (Koga et al., 1998). The results are expressed as the percentage of inhibition of amB-induced hemolysis, calculated according to the following formula: hemolysis inhibition $\%=[(\mathrm{Ab}-\mathrm{Aa}) / \mathrm{Ab}] \times 100$, where $\mathrm{Ab}$ is the absorption of the control and $\mathrm{Aa}$ is the absorption of the sample (Dypbukt et al., 2005). 


\section{Results}

Antifungal susceptibility tests showed that both the white and black teas inhibited the growth of the yeast cells and that black tea has a higher antifungal activity than white tea in all the strains tested. This antifungal activity was dose-dependent and was less effective than the antifungal activity of amB. The amB and black tea or white tea combination markedly reduced MICs for two clinical isolates and two ATCC strains. Based on the FICIs, an additive effect was observed for amB and black tea in two strains and for amB and white tea in four strains. No effect was observed in the remaining isolates. Regardless of the MIC endpoints, no antagonism was observed between amB and either of the teas (Table 1).

To explore the toxicity of black and white teas, as well as their possible protective effect on amB-induced cytotoxicity in red blood cells, hemolysis induced by the drug was measured in the absence and presence of the teas. The inhibition of hemolysis by both the black and white teas was dose-dependent, and black tea showed a greater inhibition of hemolysis than white tea (Figure 1). Black and white teas showed an inhibition of hemolysis at a concentration 100ug.mL $\mathrm{mL}^{-1}$ of $63.31 \%$ and $52.18 \%$ respectively, while in the concentration of 50ug. $\mathrm{mL}^{-1}$ the inhibitions were respectively $59.25 \%$ and $31.95 \%$. No inhibitory effect was observed at the other tested concentrations.

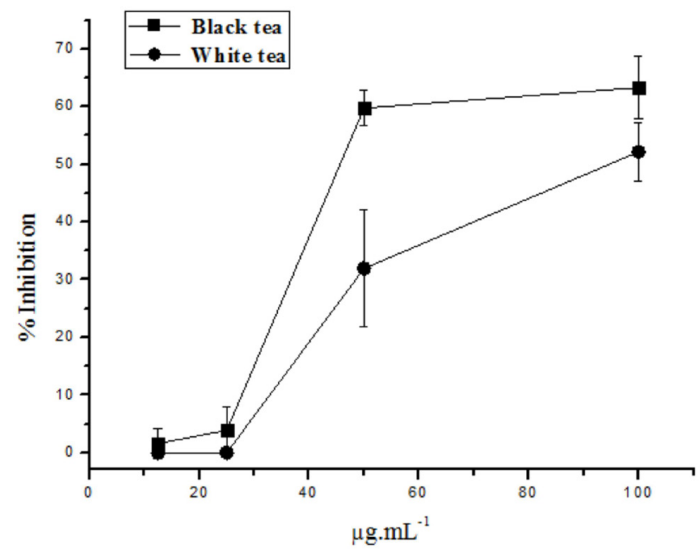

Figure 1. Inhibitory effect of white and black teas in hemolysis induced by amphotericin B.

Table 1. Antifungal activity of amB in the absence or presence of black and white teas.

\begin{tabular}{|c|c|c|c|c|c|c|c|}
\hline 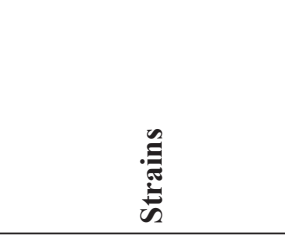 & 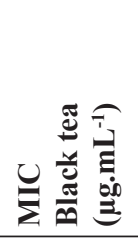 & 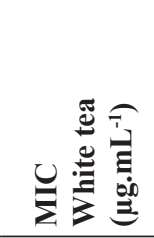 & 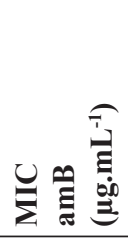 & 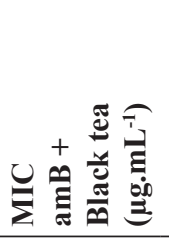 & 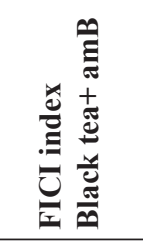 & 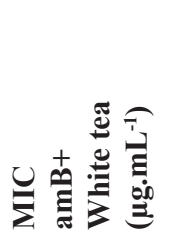 & 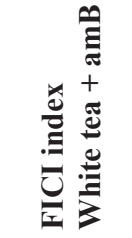 \\
\hline $\begin{array}{l}\text { Candida albicans } \\
\text { (ATCC 14053) }\end{array}$ & 29.6 & 158.4 & 0.025 & 0.025 & 2 (I) & 0.025 & 2 (I) \\
\hline $\begin{array}{l}\text { Candida albicans } \\
\text { (ATCC 64546) }\end{array}$ & 29.6 & 79.2 & 0.025 & $1.56 \times 10^{-4}$ & $0.506(\mathrm{~A})$ & $1.56 \times 10^{-4}$ & $0.506(\mathrm{~A})$ \\
\hline $\begin{array}{l}\text { Candida krusei } \\
\text { (ATCC 6258) }\end{array}$ & 14.8 & 79.2 & 0.25 & 0.25 & 2 (I) & $3.12 \times 10^{-4}$ & $0.501(\mathrm{~A})$ \\
\hline $\begin{array}{l}\text { Candida albicans } \\
\text { (LAC15) }\end{array}$ & 29.6 & 158.4 & 0.02 & 0.02 & 2 (I) & $4 \times 10^{-3}$ & 0.7 (A) \\
\hline $\begin{array}{l}\text { Candida parapsilosis } \\
\text { (LAC1) }\end{array}$ & 29.6 & 79.2 & 0.02 & $5 \times 10^{-4}$ & $0.525(\mathrm{~A})$ & $1 \times 10^{-3}$ & $0.55(\mathrm{~A})$ \\
\hline $\begin{array}{l}\text { Candida utilis } \\
\text { (LAC2) }\end{array}$ & 29.6 & 158.4 & 0.1 & 0.1 & 2 (I) & 0.1 & 2 (I) \\
\hline $\begin{array}{l}\text { Candida kefyr } \\
\text { (LAC4) }\end{array}$ & 14.8 & 79.2 & 0.1 & 0.1 & 2 (I) & 0.1 & 2 (I) \\
\hline $\begin{array}{l}\text { Candida albicans } \\
\text { (LAC3) }\end{array}$ & 14.8 & 158.4 & 0.02 & 0.02 & 2 (I) & 0.02 & $2(\mathrm{I})$ \\
\hline $\begin{array}{l}\text { Candida tropicalis } \\
\text { (LAC6) }\end{array}$ & 118.4 & $>316.8$ & 0.5 & 0.5 & 2 (I) & 0.5 & 2 (I) \\
\hline $\begin{array}{l}\text { Candida albicans } \\
\text { (LAC5) }\end{array}$ & 14.8 & 79.2 & 0.02 & 0.02 & 2 (I) & 0.02 & 2 (I) \\
\hline $\begin{array}{l}\text { Candida albicans } \\
\text { (LAC13) }\end{array}$ & 14.8 & 158.4 & 0.02 & 0.02 & 2 (I) & 0.02 & 2 (I) \\
\hline
\end{tabular}

(I) indifferent effect; (A) aditive efect. 


\section{Discussion}

The amB is toxic because of its high affinity for the ergosterol present in fungal and mammalian cell membranes. Thus, its use has been limited in many patients because it almost always results in some degree of renal impairment, which ranges in severity depending on the total dose (Sawaya et al., 1995). Thus, a more rational treatment could be the combination of amB with compounds that enhance its action, so that smaller doses of drug can be used, or with compounds that protect cells or tissues that are targets of amB-mediated toxicity. Some studies have already explored this possibility. For example, one group demonstrated the synergistic activity of grape seed extract (Vitis venifera) and amB against Candida $\mathrm{sp}$ (Han, 2007b). This effect was also observed when amB was combined with the natural compound berberine (Han and Lee, 2005). The present study demonstrated the effect of black and white teas on the antifungal activity of amB and its toxicity to human erythrocytes.

The antifungal susceptibility tests showed that white and black teas have antifungal activities for different species. Others studies also suggest that a compound isolated from the white tea, has an antifungal effect on C. albicans due to the inhibition of ergosterol synthesis (Navarro-Martinez et al., 2006; Park et al., 2006). Tea and some phenolic compounds as theaflavin digallate, has also display antibacterial and antifungal activity (Okubo et al., 1991; Hassani et al., 2009). Although compounds isolated from teas exhibit antifungal activity, the tea itself may be more effective. Due to the complexity of the tea composition, many interactions can occur between the compounds in tea infusions, leading to synergistic or antagonistic effects (Williamson, 2001). The composition of the teas of this study was carried out in other published work, through the Folin-Ciocalteu assay. This method showed a high overall content of phenols in the tested teas (Camargo et al., 2016). This study also shows the effect of black and white teas on the MIC of amB for some Candida sp. strains. According to the FICI values, this effect is additive. Although black tea has a higher antifungal activity, an additive effect of white tea and amB was observed in a greater number of strains. Han (2007a) also showed that epigallocatechin gallate, a compound isolated from white tea, has a synergistic effect with amB both in vitro and in vivo. An additive effect was also observed in some strains of C.albicans, C. krusei, and C.parapsilosis. This suggests that the additive effect may be restricted to certain types of species, which implies varying susceptibility patterns for each species. The genetic diversity within and among the different species analyzed must also be considered (Wang et al., 2007).

In addition, our results suggested that white and black tea was a potential agent to combine with $\mathrm{amB}$ for increase antifungal efficacy and to reduce the amB dose to lessen side effects. The combination may reduce the toxicity in red blood cells.

The results from the hemolysis tests show that black and white teas have a protective effect on the toxicity induced in vitro by amB. Brajtburg et al. (1985), suggests oxidative damage as a component in the anticellular effect of amB and particularly its lytic action. It is demonstrated that drug-induced hemolysis was delayed in the presence of the antioxidant catalase, while accelerated of lysis was observed in the presence of pro-oxidants such as ascorbate. This suggests that the protective effect observed for white and black teas may be related to antioxidant mechanisms because this activity is well established in C.sinensis teas.

However, a limitation on the use of tea infusions for pharmaceutical applications is the low oral bioavailability of most tea components. Due of their large molecular weight, thearubigins and some catechins are not absorbed in the intestine (Zhu et al., 2000). Mulder et al. (2001) reported that the maximum concentration of theaflavin in human plasma and urine was only $1 \mathrm{ng} \cdot \mathrm{mL}^{-1}$ and $4.2 \mathrm{ng} \cdot \mathrm{mL}^{-1}$ respectively, following consumption of $700 \mathrm{mg}$ of a pure theaflavin mixture, equivalent to approximately 30 cups of black tea. This suggests that large quantities of black or white teas would need to be consumed to achieve the benefits shown in this study. However, the bioavailability and biotransformation of tea compounds need to be studied further because quantitative data on the blood and tissue levels of tea compounds are still scarce.

\section{Conclusion}

The present study showed that white and black teas have additive antifungal effects with amB against some Candidasp. strainsand protect red blood cells from amphotericin B-mediated toxicity. Our results suggested that white and black teas could potentially be combined with amphotericin B to enhance antifungal efficacy, so that a lower dose of amphotericin B could be used to lessen side effects. Additional in vitro tests are required to perform synergy tests on other fungal strains and to evaluate the antimicrobial potential of tea infusions for new therapeutic applications.

\section{Acknowledgements}

The authors would like to thank the Brazilian agencies CAPES and CNPq for their financial support. We also gratefully acknowledge the pharmacy VicoFarma for donating the amphotericin B used in this study and the Parana State Central Laboratory (LACEN) for providing clinical isolates.

\section{References}

AGÊNCIA NACIONAL DE VIGILÂNCIA SANITÁRIA ANVISA, 2010. Farmacopeia brasileira. Brasília: Anvisa, 192 p.

ALMAJANO, M.P., CARBO, R., JIMENEZ, L.A.J. and GORDON, H.M., 2008. Antioxidant and antimicrobial activities of tea infusions. Food Chemistry, vol. 108, no. 1, pp. 55-63. http:// dx.doi.org/10.1016/j.foodchem.2007.10.040.

ARIKAN, S., LOZANO-CHIU, M., PAETZNICK, V. and REX, J.H., 2002. In Vitro Synergy of Caspofungin and Amphotericin 
B against Aspergillus and Fusarium spp. Antimicrobial Agents and Chemotherapy, vol. 46, no. 1, pp. 245-247. PMid:11751145. http://dx.doi.org/10.1128/AAC.46.1.245-247.2002.

BANCIROVA, M., 2010. Comparison of the antioxidant capacity and the antimicrobial activity of black and green tea. Food Research International, vol. 43, no. 5, pp. 1379-1382. http:// dx.doi.org/10.1016/j.foodres.2010.04.020.

BRAJTBURG, J., ELBERG, S., SCHWARTZ, D.R., VERTUTCROQUIN, A., SCHLESSINGER, D., KOBAYASHI, G.S. and MEDOFF, G., 1985. Involvement of Oxidative Damage in Erythrocyte Lysis Induced by Amphotericin B. Antimicrobial Agents and Chemotherapy, vol. 27, no. 2, pp. 172-176. PMid:3985601. http://dx.doi.org/10.1128/AAC.27.2.172.

CAMARGO, L.E.A., PEDROSO, L.S., VENDRAME, S.C., MAINARDES, R.M. and KHALIL, N.M., 2016. Antioxidant and antifungal activities of Camellia sinensis (L.) Kuntze leaves obtained by different forms of production. Brazilian Journal of Biology = Revista Brasileira de Biologia, vol. 76, no. 2, pp. 428434. PMid:26983085. http://dx.doi.org/10.1590/1519-6984.18814.

CLINICALAND LABORATORY STANDARDS INSTITUTE, 2008. M27-A3 approved standard: reference method for both dilution antifungal susceptibility testing of yeasts. 3rd ed. Wayne: Clinical and Laboratory Institute.

COLOMBO, A.L. and GUIMARAES, T., 2003. Epidemiologia das infecções hematogênicas por Candida spp. Revista da Sociedade Brasileira de Medicina Tropical, vol. 36, no. 5, pp. 599-607. PMid:14576875. http://dx.doi.org/10.1590/S003786822003000500010 .

COLOMBO, A.L., NUCCI, M., PARK, B.J., NOUÉR, S.A., ARTHINGTON-SKAGGS, B., MATTA, D.A., WARNOCK, D., MORGAN, J., and BRAZILIAN NETWORK CANDIDEMIA STUDY, 2006. Epidemiology of candidemia in Brazil: a nationwide sentinel surveillance of candidemia in eleven medical centers. Journal of Clinical Microbiology, vol. 44, no. 8, pp. 2816-2823. PMid:16891497. http://dx.doi.org/10.1128/JCM.00773-06.

DYPBUKT, J.M., BISHOP, C., BROOKS, W.M., THONG, B., ERIKSSON, H. and KETTLE, A.J., 2005. A sensitive and selective assay for chloramine production by myeloperoxidase. Free Radical Biology \& Medicine, vol. 39, no. 11, pp. 1468-1477. PMid:16274882. http://dx.doi.org/10.1016/j.freeradbiomed.2005.07.008

FILIPPIN, F. and SOUZA, L., 2006. Eficiência terapêutica das formulações lipídicas de anfotericina B. Revista Brasileira de Ciências Farmacêuticas, vol. 42, no. 2, pp. 167-194. http://dx.doi. org/10.1590/S1516-93322006000200003.

FRIEDMAN, M., 2007. Overview of antibacterial, antitoxin, antiviral, and antifungal activities of tea flavonoids and teas. Molecular Nutrition \& Food Research, vol. 51, no. 1, pp. 116134. PMid:17195249. http://dx.doi.org/10.1002/mnfr.200600173.

FUKUI, H., KOIKE, T., SAHEKI, A., SONOKE, S., TOMII, Y. and SEKI, J., 2003. Evaluation of the efficacy and toxicity of amphotericin B incorporated in lipid nano-sphere $\left(\mathrm{LNS}^{\circledR}\right)$. International Journal of Pharmaceutics, vol. 263, no. 1-2, pp. 51-60. PMid:12954180. http://dx.doi.org/10.1016/S03785173(03)00342-9.

HAN, Y. and LEE, J.H., 2005. Berberine Synergy with Amphotericin B against Disseminated Candidiasis in Mice. Biological \& Pharmaceutical Bulletin, vol. 28, no. 3, pp. 541-544. PMid:15744087. http://dx.doi.org/10.1248/bpb.28.541.
HAN, Y., 2007a. Synergic Anticandidal Effect of Epigallocatechin$O$-gallate Combined with Amphotericin B in a Murine Model of Disseminated Candidiasis and Its Anticandidal Mechanism. Biological \& Pharmaceutical Bulletin, vol. 30, no. 9, pp. 16931696. PMid:17827722. http://dx.doi.org/10.1248/bpb.30.1693.

HAN, Y., 2007b. Synergic effect of grape seed extract with amphotericin B against disseminated candidiasis due to Candida albicans. Phytomedicine, vol. 14, no. 11, pp. 733-738. PMid:17913484. http://dx.doi.org/10.1016/j.phymed.2007.08.004.

HASSANI, A.R., ORDOUZADEH, N., GHAEMI, A., AMIRMOZAFARI, N., HAMDI, K. and NAZARI, R., 2009. In vitro inhibition of Helicobacter pylori urease with non and semi fermented Camellia sinensis. Indian Journal of Medical Microbiology, vol. 27, no. 1, pp. 30-34. PMid:19172056.

JUNG, S.H., LIM, D.H., JUNG, S.H., LEE, J.E., JEONG, K.S., SEONG, H. and SHIN, B.C., 2009. Amphotericin B-entrapping lipid nanoparticles and their in vitro and in vivo characteristics. European Journal of Pharmaceutical Sciences, vol. 37, no. 3-4, pp. 313-320. PMid:19491021. http://dx.doi.org/10.1016/j. ejps.2009.02.021.

KOGA, T., MORO, K. and TERAO, J., 1998. Protective effects of a vitamin $\mathrm{E}$ analog, phosphatidylchromanol, against oxidative hemolysis of human erythrocytes. Lipids, vol. 33, no. 6, pp. 589595. PMid:9655374. http://dx.doi.org/10.1007/s11745-998-0244-4.

MULDER, T.P.J., VAN PLATERINK, C.J., SCHUYL, P.J.W. and VAN AMELSVOORT, J.M.M., 2001. Analysis of theaflavins in biological fluids using liquid chromatography-electrospraymass spectrometry. Journal of Chromatography. B, Biomedical Sciences and Applications, vol. 760, no. 2, pp. 271-279. PMid:11530986. http://dx.doi.org/10.1016/S0378-4347(01)00285-7.

NAVARRO-MARTÍNEZ, M.D., GARCÍA-CÁNOVAS, F. and RODRÍGUEZ-LÓPEZ, J.N., 2006. Tea polyphenol epigallocatechin3-gallate inhibits ergosterol synthesis by disturbing folic acid metabolism in Candida albicans. The Journal of Antimicrobial Chemotherapy, vol. 57, no. 6, pp. 1083-1092. PMid:16585130. http://dx.doi.org/10.1093/jac/dk1124.

ODDS, F.C., 2003. Synergy, antagonism, and what the chequerboard puts between them. The Journal of Antimicrobial Chemotherapy, vol. 52, no. 1, pp. 1. PMid:12805255. http://dx.doi.org/10.1093/ $\mathrm{jac} / \mathrm{dkg} 301$.

OKUBO, S., TODA, M., HARA, Y. and SHIMAMURA, T., 1991. Antifungal and fungicidal activities of tea extract and catechin against Trichophyton. Nihon Saikingaku Zasshi: Japanese Journal of Bacteriology, vol. 46, no. 2, pp. 509-514. In japanese. PMid:2062004. http://dx.doi.org/10.3412/jsb.46.509.

PAGANO, L., CAIRA, M., VALENTINI, C.G., POSTERARO, B. and FIANCHI, L., 2010. Current therapeutic approaches to fungal infections in immunocompromised hematological patients. Blood Reviews, vol. 24, no. 2, pp. 51-61. PMid:20056300. http:// dx.doi.org/10.1016/j.blre.2009.11.003.

PARK, B.J., PARK, J.C., TAGUCHI, H., FUKUSHIMA, K., HYON, S.H. and TAKATORI, K., 2006. Antifungal susceptibility of epigallocatechin 3-O-gallate (EGCg) on clinical isolates of pathogenic yeasts. Biochemical and Biophysical Research Communications, vol. 347, no. 2, pp. 401-405. PMid:16831406. http://dx.doi.org/10.1016/j.bbrc.2006.06.037.

PFALLER, M.A., 2012. Antifungal Drug Resistance: Mechanisms, Epidemiology, and Consequences for Treatment. The American Journal of Medicine, vol. 125, no. 1, suppl., pp. 3-13. PMid:22196207. http://dx.doi.org/10.1016/j.amjmed.2011.11.001. 
ROSATO, A., VITALI, C., GALLO, D., BALENZANO, L. and MALLAMACI, R., 2008. The inhibition of Candida species by selected essential oils and their synergism with amphotericin B. Phytomedicine, vol. 15, no. 8, pp. 635-638. PMid:18579358. http://dx.doi.org/10.1016/j.phymed.2008.05.001.

SAWAYA, B.P., BRIGGS, J.P. and SCHNERMANN, J., 1995. Amphotericin B nephrotoxicity: the adverse consequences of altered membrane properties. Journal of the American Society of Nephrology, vol. 6, no. 2, pp. 154-164. PMid:7579079.

SITHEEQUE, M.A., PANAGODA, G.J., YAU, J., AMARAKOON, A.M., UDAGAMA, U.R. and SAMARANAYAKE, L.P., 2009. Antifungal activity of black tea polyphenols (catechins and theaflavins) against Candida species. Chemotherapy, vol. 55, no. 3, pp. 189-196. PMid:19420933. http://dx.doi. org/10.1159/000216836.

TIWARI, T.P., BHARTI, S.K., KAUR, H.D., DIKSHIT, R.P. and HOONDAL, G.S., 2005. Synergistic antimicrobial activity of tea $\&$ antibiotics. The Indian Journal of Medical Research, vol. 122, no. 1, pp. 80-84. PMid:16106094.

TUMBARELLO, M., POSTERARO, B., TRECARICHI, E.M., FIORI, B., ROSSI, M., PORTA, R., DONATI, K.G., SORDA, M., SPANU, T., FADDA, G., CAUDA, R. and SANGUINETTI,
M., 2007. Biofilm Production by Candida Species and Inadequate Antifungal Therapy as Predictors of Mortality for Patients with Candidemia. Journal of Clinical Microbiology, vol. 45, no. 6, pp. 1843-1850. PMid:17460052. http://dx.doi.org/10.1128/ JCM.00131-07.

WANG, J.S., LI, S.Y., YANG, Y.L., CHOU, H.H. and LO, H.J., 2007. Association between fluconazole susceptibility and genetic relatedness among Candida tropicalis isolates in Taiwan. Journal of Medical Microbiology, vol. 56, no. Pt 5, pp. 650-653. PMid:17446288. http://dx.doi.org/10.1099/jmm.0.46664-0.

WENZEL, R.P., 1995. Nosocomial candidemia: risk factors and attributable mortality. Clinical Infectious Diseases, vol. 20, no. 6, pp. 1531-1534. PMid:7548504. http://dx.doi.org/10.1093/ clinids/20.6.1531.

WILLIAMSON, E.M., 2001. Synergy and other interactions in phytomedicines. Phytomedicine, vol. 8, no. 5, pp. 401-409. PMid:11695885. http://dx.doi.org/10.1078/0944-7113-00060.

ZHU, M., CHEN, Y. and LI, C.R., 2000. Oral absorption and Bioavailability of Tea catechins. Planta Medica, vol. 66, no. 5, pp. 444-447. PMid:10909265. http://dx.doi.org/10.1055/s-2000-8599. 